\title{
The People's Democracy Party
}

\section{Aylin Güney}

To cite this article: Aylin Güney (2002) The People's Democracy Party, Turkish Studies, 3:1, 122-137, DOI: $10.1080 / 714005704$

To link to this article: https://doi.org/10.1080/714005704

曲 Published online: 08 Sep 2010.

Submit your article to this journal

Шll Article views: 248

4 Citing articles: 6 View citing articles 둔 


\title{
The People's Democracy Party
}

\author{
AYLIN GÜNEY
}

The Kurdish problem has existed in Turkey since the inception of the Republic (1923), yet the formation of opposition parties, which brought the problem to the public space, did not take place until the end of the Second World War. On the other hand, Turkish law has always insisted that all political parties embrace the whole nation, banning, among other things, parties based on regionalism and ethnicity.

It was after the first military coup in 1960-61 that some political parties began to assume specifically religious or ethnic colors, thanks to the liberal 1961 Constitution. ${ }^{1}$ In this relatively free political environment, such rightwing political parties as the New Turkey Party (Yeni Türkiye Partisi-YTP) and left-wing political parties such as the Turkish Workers' Party (Türkiye Isş̧i Partisi-TIP) began to exploit ethnic issues for political benefit. Most of the members of the YTP were local landlords in southeastern Turkey where Kurds (read "Kurds" as "Turkish citizens of Kurdish origin") live in great numbers. In the early 1960s, the party received more than 30 percent of the votes in that region. In the 1970 party Congress, the TiP took up the Kurdish problem, and appeared as the first legal party to recognize openly the existence of Kurds in Turkey. ${ }^{2}$

In March 1971, the military intervened in politics and all Kurdish nationalist activity was repressed. The coup-by-pronunciamento was an attempt by the military to defend what it perceived to be a weakened state under assault by Leftists, Islamists, and Kurds. The coup tried to maintain the hegemony of the Republican political philosophy. ${ }^{3}$ This was considered a must for safeguarding national unity and the territorial integrity of the country.

The political discourse of the late 1960s stressed underdevelopment as the primary cause of the Kurdish problem. In the 1970s, despite the 1971 military intervention and the subsequent amending of the Constitution in an authoritarian direction, one that focused on ethnicity replaced the discourse of underdevelopment. The TiP and some student groups kept the Kurdish issue on the political agenda. They argued that by pursuing 
capitalist and imperialist policies the state had denied the existence of Kurdish identity and, furthermore, had not made a genuine effort to develop the Southeast economically.

Initially, the TIP and other groups aimed at persuading the government to recognize the Kurdish language and grant cultural rights to the Kurds. Later, however, their rhetoric became revolutionary and even secessionist. ${ }^{4}$ This led to armed confrontations between the radical Marxists and rightwing ultra-nationalists, bringing serious political and social instability to Turkey.

The ideological turmoil and political instability as well as the worsening of the economy in the 1970s culminated in another military intervention (September 1980). The indivisibility of the Turkish state and nation was reiterated in the 1982 Constitution, which was the handwork of the interveners. The Constitution defined being a Turk in a non-ethnic sense, stipulating that "everyone bound to the Turkish state through the bond of citizenship is a Turk." Still, this provision implied that the recognition of a separate Kurdish ethnic identity was not admissible. Clearly, the military sought to revitalize Turkish nationalism, through civic nationalism based on citizenship. The military and some members of the intelligentsia viewed religion as a political tool to boost national unity and weaken the influence of the Marxist and separatist ideas, an approach that was known as "Turkish-Islamic synthesis."

Nevertheless, these policies did not prevent the radical Kurdish groups from intensifying their activities under the banner of an illegal party, the Kurdistan Workers Party (Partiya Karkaren Kürdistan-PKK), which was led by Abdullah Öcalan. From the beginning, the PKK described itself as Marxist-Leninist. It adopted the left-wing anti-imperialist rhetoric of the period. The PKK opposed "Turkish imperialism," which, it argued, was prevalent in "Turkish Kurdistan." The party consequently declared its goal to be the creation of a unified and independent Kurdish state, ${ }^{7}$ and engaged in terrorist activities. After a while, the PKK perpetrated its terrorist activities from its headquarters in Lebanon and Syria. By the end of 1992, the PKK terrorist campaign had taken more than 5,000 lives. The situation deteriorated as years went on. Before the hostilities came to a lull in early 1999, that number had climbed to 30,000 .

In the meantime, that is from 1990 onwards, legal Kurdish-oriented political parties, planing to run for election in the parliament, began to form in Turkey. The People's Democracy Party (Halkın Demokrasi Partisi-HADEP) is such a political party in present-day Turkey. Concerning HADEP, as well as the political parties that preceded it, there 
is not much information on such issues as leadership patterns, and the internal structure and functioning of the party. After briefly discussing its predecessors, this contribution takes up first HADEP's electoral support, its approach to the issue of the Kurdish question, and its views on the state and democracy. Finally, it attempts to assess the degree to which HADEP would contribute or obstruct the consolidation and deepening of democracy in Turkey.

In order to place this narrative on the Kurdish oriented political parties, including HADEP, into context, it is important to note that the unitary state in Turkey has always been suspicious towards the issue of ethnicity. The first and foremost factor here was the intermittent Kurdish riots from 1925 to 1938. The second, and the more immediate factor, was the terrorist activities of the PKK, and the latter's ultimate aim of founding an independent Kurdish state.

The sensitivity on this issue lessened somewhat following the Gulf War. Some political leaders appeared to be willing to give legal Kurdish parties a chance. Turgut Özal, prime minister from 1983 until 1990 and president from 1990 until 1993, openly acknowledged the "Kurdish reality." In 1987, he even persuaded the parliament to remove from the statute book the provision that in 1983 had indirectly banned the use of Kurdish. ${ }^{8}$ Yet, the death of Özal marked a return to the earlier stance on the Kurdish issue. That approach has lingered to this day, despite the fact that in the early 1990s Süleyman Demirel as president, and Erdal İnönü as leader of the Social Democratic People's Party (Sosyal Demokrat Halkçı Parti-SHP), had spoken publicly of the "Kurdish reality."

\section{FROM HEP TO HADEP}

The first of the pro-Kurdish parties in Turkey was the People's Work Party (Halkin Emek Partisi-HEP). This party was formed on June 7, 1990 by seven members of parliament who had been expelled from the SHP for attending a conference in Paris on the Kurdish question. At the October 1991 national elections, HEP and the SHP merged and former HEP deputies ran on the SHP ticket and won the elections. Then, while taking their oath in the parliament, several former HEP deputies switched to the Kurdish language and displayed colors associated with the PKK. Soon after this incident, they left the SHP to re-establish HEP. Due to the overt promotion of Kurdish political and cultural rights, albeit formulated within the larger framework of "the right to self-determination," HEP was banned by the Constitutional Court in July 1993. The court's decision was on the 
grounds that the party had become a focus of illegal political pursuits and was engaged in activities against "the indivisible unity of the state with its territory and people." $"$

HEP was succeeded by the Democracy Party (Demokrasi PartisiDEP), which was generally viewed in political circles as a replica of HEP. ${ }^{10}$ DEP was founded in May 1993 by a group of politicians that included many prominent HEP parliamentarians. The latter had resigned from HEP because of the probability of the closure of their party in the near future. Under DEP, the leadership cadres became increasingly divided over the question of how much support to give to the PKK. Eventually, a division emerged between a moderate flank and a radical group. Hatip Dicle, a deputy from the city of Diyarbakir in the southeast, was the leader of the radicals. ${ }^{11}$ DEP acted in an even more adversarial manner than its predecessor. It showed much less sensitivity towards mainstream Turkish public opinion. In February 1994, a PKK bomb killed a group of young military cadets in a railway station near Istanbul. Dicle publicly declared, "In war, everyone in uniform is a target." ${ }^{2}$ At a DEP Congress, he also argued that the PKK is a political, not a terrorist, organization. ${ }^{13}$ Another leading member of DEP referred to the PKK's terrorist activities as a struggle for "an independent and unified Kurdish state," and demanded a political solution to the Kurdish question. ${ }^{14}$ Consequently, the parliamentary immunity of the DEP deputies of Kurdish origin was removed in March 1994. Six DEP deputies were arrested, found guilty and sentenced to 15 years imprisonment. The party was closed in June 1994 by the Constitutional Court on the grounds that Dicle and other DEP members had made provocative statements against the Turkish Republic.

As noted, HADEP emerged as the next Kurdish-oriented party. In May 1994, Murat Bozlak, a lawyer, founded the party. Initially, HADEP seemed to have a moderate stance towards the Kurdish question and kept its distance from the PKK. It also chose not to join the parliament-in-exile in the Netherlands. Therefore, HADEP avoided the limelight until its disastrous party Congress in June 1996.

At the said Congress, masked men let the Turkish flag drop on the floor and raised the PKK banner in its place. As a result of this incident, all HADEP members, including the party's leader, were arrested. All but one of the defendants was charged with belonging to or leading an illegal armed group, under Article 168 of the Turkish Penal Code. The public prosecutor argued that HADEP had acted as a front for the PKK. The press releases of the PKK's news agency and pro-PKK journals and magazines found in the offices of HADEP members were presented as evidence of the 
close relationship between HADEP and the PKK. The insult committed against the Turkish flag at the HADEP Congress seems to have been the last straw. The public prosecutor argued that the HADEP leadership had done nothing to put an end to those acts. Bozlak later denied it, pointing out that they had immediately denounced that provocative act..$^{15}$

One gets the impression that in HADEP, as in its predecessor, DEP, there was a tug-of-war between the moderates and the radicals, and the above acts were the handwork of the latter. At HADEP's November 1998 party Congress, leaders advised calm to the delegates. In fact, they worked closely with police to insure that incidents similar to those in the 1996 Congress would not take place. Mehmet Satan, a member of the Central Committee of HADEP, stated at a news conference that "there were efforts to create hatred between Kurds and Turks [read 'Turks' as 'Turkish citizens of Turkish origin']. We called on everyone to act in a responsible manner and refrain from acts that would incite enmity between the Turks and the Kurds."${ }^{\prime 16}$

The arrest of the PKK leader, Abdullah Öcalan, in February 1999 put a strain on HADEP's efforts to remain "moderate." ${ }^{17}$ Until recently, HADEP had not openly denied its association with the PKK. In January 1999, the public prosecutor asked the Constitutional Court to close the party on the grounds that there had been an organic link between HADEP and the PKK. The prosecutor argued that the HADEP Congresses had turned into an arena of support for Öcalan. He added that the seminars held by the local branches of the party were used as a means of inculcating enmity towards the state and the constitutional order the latter rests upon. According to the prosecutor, "the PKK threatened to kill people who did not vote for HADEP." ${ }^{\prime 18}$ As if to support the last accusation, in his trial Öcalan stated that the PKK had made monetary contributions to HADEP; it nominated HADEP's candidates in the national elections; and, in turn, HADEP trained militants for the PKK. ${ }^{19}$

As a result of these statements by Öcalan, the prosecutor called for preventing HADEP from competing in the April 18, 1999 national elections. The prosecutor argued that "If political parties that are established with ties to terrorist organisations are allowed to participate in the elections ... we will have in this country thousands of terrorist parliamentarians, mayors, and members of local government bodies." ${ }^{20}$

Nevertheless, HADEP entered the 1999 national elections when the Constitutional Court, which still has not come up with a ruling on the closure case of the party, rejected the prosecutor's call. ${ }^{21}$ The party had also competed in the 1995 national elections. It has been claimed that although 
HADEP had not achieved its goals in the 1995 or 1999 national elections, the party succeeded in legitimizing itself for two reasons. First, it proved that despite the long years of war and violence it was the preferred choice of the people in the southeast. Second, its poor electoral results in the major cities in other parts of the country were received with a collective sigh of relief by the Turks who had feared all along that the party would score electoral victories in regions other than the southeast. ${ }^{22}$

\section{HADEP'S ELECTORAL SUPPORT}

HADEP did not participate in the 1994 municipal elections, claiming that the state's intimidating tactics made it very difficult for the party to stage a free campaign. ${ }^{23}$ However, as noted, the party participated in the 1995 and 1999 national elections. Before the 1995 elections, HADEP also doubted whether the elections would be conducted in a free and fair manner. The party thought that the ten percent nationwide election threshold, the presence of the military security forces in most martial law areas where HADEP had strong political support, the insufficient time allowed for the displaced Kurds ${ }^{24}$ and the newly-eligible 18-year-olds to register to vote, and the heavy snows in December, which made roads impassable in most areas in the southeast, would have worked against it. In fact, the party called for observers from the "democratic peoples of the world" to monitor the elections. ${ }^{25}$

In the 1995 national elections, HADEP garnered 4.2 percent of the votes. Since its votes remained below the nationwide threshold of ten percent, it was not able to gain representation in parliament. In the southeast, HADEP tried to appeal to its Kurdish voters by seeking the support of the tribal leaders and large landowners and recruiting religious leaders as candidates. It has been suggested that in the southeast, the Kurds tilted towards the Welfare Party (Refah Partisi-RP) because they perceived it as the most anti-system party in the recent past. ${ }^{26}$ Additionally, the Islamic stance of the party was appealing to some Kurds, for traditionally Islam had been more important than ethnicity to the Kurdish communities in the southeast. ${ }^{27}$ The tribal and religious leaders in the region were conservative in the political, economic and social sense and, furthermore, tended to view HADEP as being close to the PKK. Many of those leaders had been alienated by the radical leftist discourse of the Kurdish parties like DEP and HADEP. ${ }^{28}$

Still, in the 1995 elections, relatively speaking, HADEP did quite well in the southeast. The three provinces where it did exceptionally well were 
Hakkari (54.2 percent), Diyarbakır (46.3 percent), and Batman (37.2 percent).$^{29}$ However, HADEP was defeated in large cities in other regions of the country where large numbers of Kurds lived. This was in part because the religiously oriented RP was extremely successful in garnering the votes of the Kurds who lived in the squatter settlement areas of large cities in those regions. One of the best examples of such a squatter settlement area was Sultanbeyli at the outskirts of Istanbul. In the 1995 elections, the RP obtained 56 percent of the votes in Sultanbeyli while HADEP won only 8.5 percent. In comparison to the situation in the southeast, the most important reason behind HADEP's losing votes in such neighborhoods was the RP's successful populist and clientelist policies. Distribution of food and fuel and arranging circumcisions, weddings, and funerals were among the means through which the RP successfully won the "hearts and minds" of the Kurds in those places. ${ }^{30}$ For instance, the mayor of Van, Aydın Talay, a member of the Virtue Party (Fazilet PartisiFP), ${ }^{31}$ said: "Ethnicity is not the issue here; our problem is poverty. People need help and they'll vote for the party that meets their expactations. ${ }^{{ }^{32} 2} \mathrm{He}$ added: "Some speak Kurdish, some speak Turkish, but we serve them all ... We have paved their roads and built sewers for everyone, regardless of ethnicity or political views. We delivered what they needed; that's why people voted for us. ${ }^{{ }^{33}}$ Being unorganized and not commanding large sums of funds, HADEP could not compete with the RP when it came to patronage politics.

In the 1999 national elections, HADEP's overall votes increased from 4.2 percent to 4.7 percent. However, since it was still unable to pass the nationwide threshold, again the party was unable to return representatives to the parliament. On the other hand, the party was still successful in the southeast. It won municipalities in seven cities there, including the biggest city of the region, with more than 1 million Kurds, Diyarbakır. In Diyarbakır, Feridun Çelik, a 33-year-old lawyer from HADEP, obtained 62.5 percent of the vote.

This time too HADEP complained of the disadvantages it faced in the elections. In an interview, the party's Deputy Chairman Ali Hıdır Doğan claimed that the party would have approached the ten percent threshold in the southeast if the state had not pressured the voters so heavily. He pointed out that before the elections, security officers stranded some 100 HADEP buses, HADEP election offices were closed down, and the party members were not able to freely conduct their campaigns except those made on a face-to-face basis. Doğan also criticized the state for refusing to acknowledge the existence of a Kurdish problem. He said: "If you say that 
there is no Kurdish problem in Turkey, you create an atmosphere for the repetition of unwanted incidents ... The problem exists and a solution for this problem should be found ... If you deny the existence of the problem, you legitimize its sources." ${ }^{34}$

\section{THE HADEP AND THE KURDISH QUESTION}

Not unexpectedly, one of the major issues that HADEP has addressed in its party program is the Kurdish problem. It is stated that the Kurdish problem remains one of the most important problems that Turkey should resolve. The party program argues that Turkey has been facing this problem because of the wrong policies that not only prevented democratization, but also impeded economic and social development by channeling a large part of the resources to military expenditures. ${ }^{35}$ It points out that the Kurdish problem should be resolved by peaceful means, achieving economic development and improving democracy. ${ }^{36}$

HADEP has certain policy proposals for solving the Kurdish problem. First, it underlines the need for the adoption of "constitutional citizenship." The party points out that one should not try to promote national unity on the basis of cultural affinity or blood ties, but rather on the foundation of the voluntary loyalty of citizens to the state. Therefore, Kurdishness or other cultural identities should not be viewed as incompatible with the overarching identity of Turkish citizenship. Secondly, the party suggests that some special provisions adopted with a view to the Kurds should be abolished. These include the ban on non-Turkish names for persons and towns, the ban on education and broadcasting in Kurdish, and the restrictions on political activities carried out in Kurdish. Thirdly, the party proposes that some specific economic and social measures should be adopted for the southeast, through a Regional Economic Development Plan. ${ }^{37}$ HADEP sees land reform as a must because a great majority of the peasants are landless, and draws attention to the fact it is impossible to improve agriculture in the border areas of the region to the south since they are full of mine-fields. HADEP perceives reviving animal-breeding in the region as a necessity since it used to be the major source of income for the inhabitants. The party is also in favor of forming free trade zones and re-starting trade across the borders. Turning to social issues, HADEP notes that the government should pay greater attention to the issues of unemployment insurance, social security, education, health, and cultural services. In addition to all of the above, the party argues that the local governments should be financially strengthened, with their debts covered by the Treasury. ${ }^{38}$ 
The most important reason behind the closure of the earlier Kurdish parties was their perceived links to the PKK. Therefore, it is important to note here how HADEP approaches the PKK issue. HADEP calls for a peaceful resolution of the conflict between the military and the PKK. As noted, for a long time the party hesitated to deny its linkage to the PKK. In recent years, however, HADEP has adopted a different discourse on this issue. In June 1999, HADEP's mayor in the town of Kiz1ltepe in Mardin province visited the family of a policeman killed by the PKK terrorists and expressed his condolences. His statement, "Enough is enough. We all suffered a great deal" ${ }^{39}$ may be taken as a sign of willingness on the part of HADEP to disassociate itself from the PKK. The mayor of Diyarbakır, Feridun Çelik, also made similar statements. On one occasion Çelik stated: "From now on we should leave this debate behind and start to think how we shall be able live together as Turks, Kurds, Lazes, and Circassians, so that we can jointly work for this country." 40 Regarding a new project initiated by his municipality, Çelik said: "This [new project] will be a sign that we are neither separatists nor against the state." ${ }^{11}$ Most recently HADEP leader Bozlak stated:

It was claimed that HADEP has been the political arm of the PKK. It is not true. This is not something we claim today. We made the same point in 1996 ... Let me point out in all my sincerity: HADEP is not a separatist party. Neither is it a vulgar nationalist party. Ours is a leftist mass party. We have never perceived ourselves as a Kurdish Party ... All of those who died [in the armed conflict] are our children ... [In one of our meetings in Istanbul] ... [w]e brought together the mother of a soldier who had died with the mother of a young man from the Southeast who also lost his life on top of a bus, and pleaded with everybody that from now on we should put an end to the loss of lives ... Yet we are still seen as a Kurdish party. ${ }^{42}$

Indeed, HADEP continues to be perceived with suspicion by the state authorities. A recent report entitled "The Domestic and International Institutions and Power of the Terrorist Organization PKK," ${ }^{43}$ prepared by the Turkish Intelligence Agency, stated that after Öcalan's capture, the PKK tended to slide towards a political platform, starting an intensive propaganda campaign along those lines through its broadcasting channels in Europe. The report listed HADEP as one of the organizations that provide support to the PKK; it claimed that the PKK aimed to supervise the activities of the municipalities controlled by HADEP. 
This particular perception of HADEP frequently led the state authorities to take stern measures against the party. In February 2000, four Kurdish mayors (of the cities of Diyarbakır, Siirt, Bingöl, and Ağrl) were charged with promoting the Kurdish cause by providing funds for the PKK and taking instructions from it. The mayors were summarily removed from their posts by the Ministry of Interior, and then taken into custody ${ }^{44}$ While HADEP Deputy Chairman Ahmet Turan Demir discussed this development at a press conference, one journalist asked: "It is claimed that the PKK is trying to politicize the Kurdish problem. What are your views on this?" Demir replied:

We want everyone to have the right to freely engage in politics. If the PKK wants to engage in politics in a way that accords with Turkey's laws and regulations, then the necessary legal and constitutional groundwork should be prepared for this. If the creation of an environment that will preclude a return to violence is desired, then we should welcome this. Whoever wants to participate in politics in accordance with the State's laws and the regulations, the ground should be prepared for this. This is one of the criteria for democracy. ${ }^{45}$

HADEP does not seem to have been demoralized by the four-mayor incident. Its Diyarbakır Provincial Chairman, Ali Ürküt, recently declared: "Despite everything, we will continue our struggle for peace and democracy." ${ }^{\prime 4}$

The removal of the mayors from their posts was contested by such European countries as Switzerland and Germany as well as by Amnesty International and the European Parliament. Some circles in Europe viewed the mayors as the very persons who could start a non-violent Kurdish political movement. ${ }^{47}$ However, President Süleyman Demirel stated that "each and every state has the right to implement its own laws and regulations, and Europe has no right to pressure Turkey not to apply its laws." ${ }^{48}$

\section{HADEP, STATE, AND DEMOCRACY}

HADEP has severely criticized the political regime in Turkey, noting that it is an "oligarchic Republic," and that a "democratic Republic" should replace it. ${ }^{49}$ The main target of criticism has been the state, which is perceived as an authoritarian and centralist state that disregards the rule of law. ${ }^{50}$ HADEP also criticizes the state for always having pursued an 
“assimiliationist policy" towards non-Turks by being engaged in an "imperialist, racist, and chauvinist-nationalist oppression upon the cultural life of the people." 51

As noted, HADEP saw democracy and democratization as the only way to solve, among others, the Kurdish problem. According to the party, the ending of the armed conflict between the government forces and the PKK is a golden opportunity for democratization. It proposed some concrete reforms for democratizing the political regime in Turkey. Among other things, the party considers the "problem of civilianization" as an important issue of Turkish democracy. Under this heading, two issues are emphasized: One is the question of which ministry the chief of the general staff should be accountable to. In Turkey, the chief of the general staff reports to prime minister, the rationale being that if he reported to the minister of defense that office would be politicized. HADEP is critical of this arrangement, noting that in parliamentary systems of government, the chief of the general staff is responsible to the Minister of Defense.

The second issue is the role the National Security Council (Milli Güvenlik Kurulu-MGK) plays in Turkey. ${ }^{52}$ The MGK was made up of the prime minister, the ministers of foreign affairs, internal affairs, and defense, the chief of the general staff, and four force commanders, and was chaired by the President. It made recommendations to the government on matters of internal and external security which the government had to give top priority. In HADEP's view, the fact that the number of the civilian members of the MGK, other than the President, was less than the number of the military officers in that body was unacceptable. (Following the recent constitutional amendments, the number of civilians in the MGK is less than the members of the military, and government "assesses" rather than "gives top priority" to the recommendations made by that body.) HADEP is also against the MGK's dealing with a wide scope of issues, ranging from economy, foreign policy, education, and human rights to university administration. ${ }^{53}$

According to HADEP, in addition to the problem of the civilianization of the political regime, a judicial reform is necessary. This reform should include such matters as abolishing the death penalty, a just electoral law, the removal of the threshold in the election laws, making election coalitions possible among political parties, a wider recognition of syndical rights and freedoms, the removal of legal obstacles to freedom of expression and association, freedom of conscience, and putting an end to the widespread practice of torture. The party states that the existing internal security concerns constitute the main impediment to further 
democratization but the 1982 Constitution is an additional obstacle. It suggests that that the Constitution should be replaced by "a constitution befitting a democratic civil society." ${ }^{54}$

Furthermore HADEP places emphasis on the decentralization of government, proposing the strengthening of local government and the promotion of political participation. According to the party, the supervision of the central government over the local government should be removed and government in the localities should be conducted by the "active participation of the people." In addition, the municipal, city, and town councils should be elevated to the status of "local parliaments." In line with these changes, mayors, police chiefs, and district governors should be elected rather than appointed. HADEP calls municipalities "People's Municipalities" and argues that these should be the places where the people and the municipality would embrace each other. ${ }^{55}$ The party would like to see local governments engaged in a wide range of activities, from providing animal shelters to building town museums. ${ }^{56}$ HADEP also plans to transfer responsibility for education, health, and local security services from the central government to the local governments. ${ }^{57}$

Concerning education, which, as noted, it intends to entrust to local governments, HADEP emphasizes the importance of the democratization of education. It sees the present system as being under the influence of an ethnic and chauvinistic approach. The party argues that education in Turkey produces one-dimensional persons. The party envisages an enlarged role for local governments and civil societal associations in order to overcome the inequalities the present educational system perpetuates in different regions and classes. The party intends to render universities "autonomous." 58

HADEP adopts a secular and democratic stance regarding religion. It does not approve of the present policies, which, in its opinion, discriminate between different religions and sects. The party argues that the state should withdraw from the sphere of religion. ${ }^{59}$ HADEP draws attention to "the pluralist nature of Turkey's historical heritage," and proposes that it should be preserved and, in fact, further deepened by the active participation of all segments of society.

HADEP indicates that "People's Municipalities" would contribute to the maintenance and development of local and cultural identities. The party would like to see municipalities set up radio and television stations that would broadcast in different languages and present local, cultural, artistic, literary, and folkloric programs. ${ }^{60}$ HADEP is in favor of the names of streets, squares, and institutions that fall under the jurisdiction of local governments being re-named in order to reflect local characteristics. 
HADEP draws attention to the fact that the European Union (EU), imposes certain standards for democracy and human rights. It states that "parallel to the global developments, ... [the EU] aims to institutionalize human rights and democratization ... [everywhere]." ${ }^{\prime 61}$ The party strongly supports Turkey's joining the EU, since "the tie with the EU means that standards ... stated in the Copenhagen criteria would be adopted ... [in Turkey, too]." ${ }^{2}$ Upon the release of the EU Accession Partnership Document, HADEP mayors expressed their support for the entry of Turkey into the Union in a joint declaration. They were pleased that the points the document emphasized were considered prerequisites for full membership of the EU. They included the freedom of expression, democratization, the prevention of torture, respect for human rights, the rule of law, independent judiciary, the abolition of the death penalty, education in one's mother tongue, and the like. The mayors also indicated their wish to see such reforms as the abolition of the death sentence and ending the Emergency Rule in the Southeast as soon as possible. ${ }^{63}$

\section{HADEP AND THE CONSOLIDATION OF DEMOCRACY}

Richard Gunther, P. Nikiforos Diamandouros, and Hans-Jürgen Puhle have noted that a democratic regime is consolidated "when all politically significant groups regard its political institutions as the only legitimate framework for political contestation, and adhere to the democratic rules of the game. ${ }^{964}$ They have further pointed out that one broad indicator of consolidation is the absence of either a politically significant anti-system party, or a semi-loyal party with the same status. An anti-system party is unequivocally opposed to the existing regime. A semi-loyal party does not overtly reject the institutions or norms of a political regime, but nevertheless maintains an ambiguous stance towards it. ${ }^{65}$ Along the same lines, Ronan Paddison has suggested that the existence of regional political parties clearly is a sign of the fact that a national political integration has not taken place. Paddison states that such parties are by definition tied to a territory, embracing only part of the state, their objectives being generally to mobilize support across ethnic, religious or class lines and winning concessions, including autonomy, or even the right to secede from the state. ${ }^{66} \mathrm{In}$ his opinion, regional parties pose a threat to the state, especially when the state is a unitary one. Another scholar, Donald Horowitz, states that "democracy can not survive in the face of serious ethnic divisions" and that "unless precautions are taken, democratic arrangements tend to unravel in ethnically divided societies in the form of ethnically based parties. ${ }^{967}$ 
Henri J. Barkey and Graham Fuller have argued that Turkey does not possess any of the problematic characteristics noted by the above authors for two reasons. First, the Kurds constitute a minority (though a large one) and second, and more importantly, whenever they were given the opportunity to vote for a distinctly ethnic party or a mainstream party Kurds tended to split their votes between those two parties. ${ }^{68}$ Andrew Mango has claimed that if the ban on ethnic parties were lifted, it would be reasonable to expect the emergence of not one but several Kurdish parties, reflecting the deep divisions within Kurdish society. ${ }^{69}$ Michael Gunter has concluded that the deep divisions among the Kurdish population prevent them from acting politically as a homogenous group. Kurdish language is divided into three major dialects (Kurdi, Kurmaji, and Zaza); Kurdi is further divided into distinct sub-dialects. ${ }^{70}$ The Kurds are also divided in the religious sense. Although most Kurds are Sunni Muslims, others are Alevis or attracted to various Dervish orders. The existence of feudal landlords, tribal chieftains, and sheikhs (religious leaders) are the basic obstacles on the way to form a regional nationalism. ${ }^{71}$

Turning to HADEP itself, the 1999 elections seem to have made an important impact upon the party's discourse and praxis. As a consequence of the Constitutional Court's decision to allow it to enter the national elections, the party gained a new dynamism and motivation. Despite the internal divisions within the party, HADEP in general seemed to be moving towards a more politically moderate stance. The party has pointed out that its candidates are technocrats rather than militants and that it is a sign of HADEP's willingness to change. ${ }^{72}$ Also, the party no longer wants to be perceived as a one-issue, that is a solely Kurdish-oriented, party. Furthermore, the HADEP has underlined the fact that its party program encompasses a wide range of issues and addresses all the major problems Turkey faces. ${ }^{73}$ Here it must also be noted that the recent statements of HADEP leaders give the impression that they are indeed after normalization in politics.

On the other hand, leading rebel commanders of the PKK are said to have played a decisive role in the selection of HADEP's list of candidates in the recent elections. Many HADEP officials still openly voice support for the PKK and some have taken part in hunger strikes staged in support of Abdullah Öcalan. Some party supporters in the southeast see a link between HADEP and the PKK, claiming that "voting for HADEP is like voting for the PKK." ${ }^{74}$

HADEP's contribution to the consolidation of democracy in Turkey depends on the degree to which their wish for normalization claimed by its leaders is genuine, and on the extent to which they will be able to convince 
the political class in Turkey that their discourse is not just double-talk. HADEP would not pose an obstacle to the consolidation of democracy in Turkey if it indisputably separates itself from the PKK and becomes a party that addresses itself to all the major problems Turkey faces, including the Kurdish issue. If HADEP successfully fulfils both of these requirements, that is, if it becomes a system party, it would usefully contribute to the deepening of democracy in Turkey.

\section{NOTES}

1. Andrew Mango, Turkey: The Challenge of a New Role (Westport, CT: Praeger, 1994), p.41.

2. Kemal Kirișçi and Gareth M. Winrow, The Kurdish Question and Turkey. An Example of a TransState Ethnic Conflict (London and Portland, OR: Frank Cass, 1997), pp.107-8.

3. Henri Barkey, "The Struggles of a 'Strong' State," Journal of International Affairs, Vol.54, No.1 (Fall 2000), p.92.

4. Kirișçi and Winrow (1997), p.109.

5. Mango (1994), p.42.

6. Kirişçi and Winrow (1997), p.112.

7. Henri J. Barkey and Graham E. Fuller, Turkey's Kurdish Question (Lanham and Boulder: Rowman and Littlefield, 1998), Ch.2.

8. Mango (1994), p.47.

9. Nicole F. Watts, "Allies and Enemies: Pro-Kurdish Parties in Turkish Politics, 1990-1994," International Journal of Middle East Studies, Vol.31, No.4 (Nov. 1999), p.639.

10. Mark Muller, "Nationalism and the Rule of Law in Turkey: The Elimination of Kurdish Representation during the 1990s," in Robert Olson (ed.), The Kurdish Nationalist Movement in the 1990s: Its Impact on Turkey and the Middle East (Lexington, KY: University of Kentucky Press, 1996), p.187.

11. Watts (1999), p.638.

12. Sabah (Istanbul daily), Feb. 17, 1994.

13. Watts (1999), p.648.

14. Muller (1996), p.188.

15. Hürriyet (Istanbul daily), Sept. 3, 2001.

16. Reuters, Nov. 18, 1998.

17. Watts (1999), p.649.

18. Reuters, April 7, 1999.

19. Hürriyet (Istanbul daily), March 18, 1999.

20. Reuters, April 9, 1999.

21. Milliyet (Istanbul daily), March 9, 1999. At the present time of writing (December 2001), the HADEP leaders have been aquitted by the State Security Court. However, the Constitutional Court's verdict is still pending.

22. Barkey and Fuller (1998), p.87.

23. Ibid., p.86.

24. HADEP expected to capture lion's share of the Kurdish vote of the people displaced by the insurgency in the southeast and moved to coastal cities like Adana, Mersin, and Istanbul. However, most of these people were unable to vote because they could not register at such a short notice. See Henri Barkey, "The People's Democracy Party (HADEP): The Travails of a Legal Kurdish Party in Turkey," Journal of Muslim Minority Affairs, Vol.18, No.1 (1998), pp.133-4.

25. HADEP Statement Concerning Upcoming Elections in Turkey, Dec. 4, 1995.

26. Barkey (1998), p.132.

27. Ibid.

28. Barkey and Fuller (1998), pp.78-9.

29. Barkey (1998), p.132. 
30. Ibid., p.133.

31. Virtue Party (Fazilet Partisi) was the successor party to the RP.

32. Susan Gusten, "Political misfits main contenders for power in Turkey's troubled east," $<$ http://kurdstruggle.org/hadep/oppression/mar1199.htm>.

33. Ibid.

34. Turkish Daily News (Ankara daily), April 29, 1999.

35. HADEP-Halkın Demokrasi Partisi, Parti Programı, 1995, p.1.

36. Ibid.

37. Ibid., p.12.

38. People's Democracy Party, HADEP, Year 2000 Perspectives of HADEP, $<$ http://www.hadep.org.tr/perspektif/pers1_1.htm>.

39. Metin Heper, "Turkey's European Vocation and Key Domestic Issues," unpublished manuscript (April 2000).

40. Hürriyet (Istanbul daily), Jan. 10, 2000.

41. Ibid.

42. Milliyet (Istanbul daily), Sept. 3, 2001.

43. Hürriyet (Istanbul daily), Aug. 8, 2001.

44. Agence France-Presse, Feb. 25, 2000.

45. New York Times, Feb. 25, 2000.

46. Ibid.

47. New York Times, Feb. 21, 2000.

48. Turkish Daily News (Ankara daily), Feb. 24, 2000.

49. HADEP-Halkın Demokrasi Partisi, Year 2000 Perspectives of HADEP, p.2.

50. Ibid.

51. Ibid.

52. Ibid., p.4.

53. Ibid.

54. Ibid., pp.4-5.

55. HADEP-Halkın Demokrasi Partisi, Yerel Yönetimler Planı, <http://www.hadep.org.tr/ yerel/yerel4.html>.

56. Ibid.

57. Ibid., p.3.

58. Ibid.

59. Ibid.

60. Ibid.

61. Ibid., p.1.

62. HADEP-Halkn Demokrasi Partisi, Year 2000 Perspectives of HADEP, p.2.

63. Hürriyet (Istanbul daily), Nov. 9, 2000.

64. Richard Gunther, P. Nikiforos Diamandouros, and Hans-Jürgen Puhle, "Introduction," in idem (eds.), The Politics of Democratic Consolidation: Southern Europe in Comparative Perspective (Baltimore and London: The Johns Hopkins University Press, 1995), p.7.

65. Ibid., pp.13-14.

66. Ronan Paddison, The Fragmented State: The Political Geography of Power (New York: St. Martin's Press, 1983), p.74.

67. Donald L. Horowitz, Ethnic Groups in Conflict (Berkeley, CA: University of California Press, 1985), p.681.

68. Barkey and Fuller (1998), pp.193-4.

69. Mango (1994), p.50.

70. Michael M. Gunter, The Kurds in Turkey: A Political Dilemma (Boulder, CO: Westview Press, 1990), p.5.

71. Ibid., p.6.

72. Milliyet (Istanbul daily), Sept. 21, 1998.

73. Ibid.

74. Economist, Vol.351, No.8113, March 4, 1999, p.45 